\section{Upjohn Cell Model at Royal Scottish Museum}

Following the recent interest in the two B.B.C. television programmes on "Science International", which featured Prof. Michael Swann, of the Natural History Department of the University of Edinburgh, and a group of scientists from world-wide sources, the notable background exhibit, the famous Upjohn model of a living cell magnified by 1,000,000 (Fig. 1), has been transported to the Royal Scottish Museum,

\section{Sorry, for copyright reasons some images on this page may not be available online}

Edinburgh, where it will be shown for six weeks. It was specially flown over from the United States for the two $1 \mathrm{hr}$. broadcasts, and has not been shown to the public anywhere outside the United States until its exhibition in Edinburgh at the middle of December. The model reproduces in 'Perspex', in three dimensions, the accumulated researches into cell structures employing light and electron microscopes over many years. The construction of the model was undertaken by the Upjohn Company, Kalamazoo, Michigan, and the research for it occupied some eighteen months, while the actual building, by Bill Burtin and his team of scientific model designers, took more than eight months. It is a hemisphere of $24 \mathrm{ft}$. diameter. First shown in June 1958 in San Francisco at the Convention of the American Medical Association, it was moved to a Health Exhibition in the Coliseum, New York City, and then to the Museum of Science and Industry, Chicago, Michigan. In the Royal Scottish Museum it is attracting interested crowds ranging from school classes to university - particularly medical-students. In February it is to be flown back to the United States.

\section{Training in the Use of Isotopes}

THE second of the two self-propelled mobile radioisotope laboratories given to the International Atomic Energy Agency by the Government of the United States of America in April 1958 was handed over to an agency representative at the Oak Ridge Institute of Nuclear Studies on December 11. The mobile laboratories are specifically designed to provide the tools for basic training in radioisotope handling techniques. They can tour a geographical area visiting high-schools and universities, and thereby make a training course easily available. At the request of the Government of Mexico, this laboratory will be used at several training establishments and universities in that country during January, February and March 1960. In April, the laboratory will be sent to Argentina for a period of six months.

In Buenos Aires a course has been organized by the National Atomic Energy Commission of Argentina for the training of twenty-five experts from Latin American coun. tries in the use of radioisotopes, especially in medicine and agriculture. For this purpose, the International Atomic Energy Agency is providing the services of two lecturers: Dr. Norman Veall from the Radioisotope Laboratory, Guy's Hospital Medical School, London, and Dr. Robert Harold Wassermann from the Laboratory of Radiation-Biology, Cornell University. Japan has put at the Agency's disposal twenty fellowships of six months duration at the Isotope School of the Atomic Energy Research Institute of Japan, for training in the handling and application of radioisotopes in different fields. The Agency has secured the services of Prof. Milorad Mladjeno. vic from the Boris Kidric Institute of Nuclear Science, Belgrade, and B.B.C. Prof. James Francis Duncan from the Radiochemistry Department, University of Melboume.

The first mobile radioisotope laboratory has already been used for training purposes at the University of Vienna, and in Greece. It has just returned to Vienna after having been used at the Haus der Technik, Essen, Federal Republic of Germany, for training young radioisotope specialists, and it is expected to be used in the Far East during 1960.

\section{Physiological Examination of a Live Whale}

A 50-TON male finwhale beached on December 5 at Provincetown on the tip of Cape Cod, and Dr. John W. Kanwisher, of the Woods Hole Oceanographic Institution, and Dr. Alfred W. Senft, of the Marine Biological Laboratory, were able to carry out temperature measurements and to obtain a cardiogram before the whale died on the following day. The cardiograms showed a pulse beat of 25 a min. (human, $72 \mathrm{a}$ min.) and an estimated size of the heart of about $225 \mathrm{kgm}$., compared to some $250 \mathrm{gm}$. for a human heart. Dr. Senft also determined the timeinterval from the pacemaker to the contraction of the ventricle. As the condition of the whale deteriorated, there were changes in the cardiogram not unlike those seen in the human cardiogram when oxygenation is impaired; it appeared that the whale suffered a conduction block, a common defect in man's heart. While the cardiograms were being made, Dr. Kanwisher obtained temperature measurements and collected respiration samples from the whale's blowhole. The internal body-temperature was $92^{\circ} \mathrm{F}$., while the fins and tails had a temperature of $50^{\circ} \mathrm{F}$.; 